\title{
Effect of the Incorporation of Sugarcane Bagasse Biochar in Leaching and Bioavailability of Clomazone in Soil
}

\author{
Marcos R. F. da Silva, ${ }^{a}$ Maria E. L. R. de Queiroz, ${ }^{\circledR *, a}$ Antônio A. Neves, ${ }^{\circledR a}$ \\ Antônio A. da Silva, ${ }^{b}$ André F. de Oliveira, ${ }^{a}$ Renan L. de Oliveira, ${ }^{a}$ \\ Mariane M. Azevedo ${ }^{a}$ and Gustavo A. M. Pereira ${ }^{b}$
}

a'Departamento de Química, Universidade Federal de Viçosa, 36570-900 Viçosa-MG, Brazil

${ }^{b}$ Departamento de Fitotecnia, Universidade Federal de Viçosa, 36570-900 Viçosa-MG, Brazil

\begin{abstract}
Clomazone exhibits high water solubility, low sorption in soil colloids, and therefore can leach and contaminate deep layers of soil profile and groundwater. In this work, the effect of the incorporation of sugarcane bagasse biochar in leaching and bioavailability of clomazone in red latosol was evaluated. Soil samples amended with $1 \%(\mathrm{~m} / \mathrm{m})$ biochar were placed in different depths (0-1, 0-2.5 and 0-5 cm) on the top of polyvinyl chloride (PVC) columns filled with soil. Clomazone-based herbicide was applied, and rainfall was simulated on top of the columns. A validated chromatographic method, together with a greenhouse bioassay, were used to quantify and to evaluate the mobility and availability of clomazone along the columns. The incorporation of sugarcane bagasse biochar in the superficial layers at the column tops increased herbicide sorption, reduced its leaching and bioavailability in soil and scaled down the environmental risk of clomazone avoiding contamination of underground aquifer reservoirs.
\end{abstract}

Keywords: herbicide, liquid chromatography, mobility, agent for environmental contamination mitigation, greenhouse bioassay

\section{Introduction}

Brazil is the world's largest producer of sugarcane and its by-products. In the 15/16 crop, the national sugar and alcohol industry was responsible for the production of ca. $22 \%$ of sugar and ca. $28 \%$ of the production of ethanol produced in the world. ${ }^{1}$ In order to guarantee the high production capacity of sugarcane crops, the use of pesticides is recurrent, being herbicides the most widely used. ${ }^{2}$ In addition to environmental contamination caused by pesticides applied to crops, the sugar and alcohol industry generates ca. 200 million $\mathrm{t}$ of organic solid waste (between bagasse and filter cake) per year, which are often eliminated by burning for energy production. ${ }^{3}$

However, alternative technologies have employed sugarcane bagasse for production of high-added value materials such as second generation bioethanol, ${ }^{4}$ bio-oil, ${ }^{5,6}$ biochar, ${ }^{5,7}$ and bioplastics, ${ }^{8}$ through enzymatic hydrolysis and thermochemical processes.

\footnotetext{
*e-mail: meliana@ufv.br
}

Clomazone (CMZ) stands out among the herbicides widely used in the sugar cane crop. It is used as pre-emergence herbicide for weed control in sugarcane, cotton, rice, potato, tobacco, cassava, corn, bell pepper and soybean crops. ${ }^{9}$ Due to its low sorption by soil colloids and high water solubility (Table 1), CMZ can leach and reach deep layers of soils, where it is absorbed by plant's roots, causing injuries in sensitive plants. ${ }^{12}$ The potential impact of CMZ on groundwater is also of great concern among researchers and its risks could be higher in soil with low organic matter content. ${ }^{10,13}$ Researches have also shown that

Table 1. Physicochemical properties of $\mathrm{CMZ}^{10,11}$

Physicochemical property
molecular formula: $\mathrm{C}_{12} \mathrm{H}_{14} \mathrm{ClNO}_{2}$
molar mass: $239.7 \mathrm{~g} \mathrm{~mol}^{-1}$

$\mathrm{K}_{\mathrm{ow}}$ : octanol-water partition coefficient. 
the herbicide can be toxic for aquatic species. As a function of concentration and exposition time, CMZ can be more highly toxic to some fishes than to others. ${ }^{14,15}$

The use of biochar as an agricultural input has shown to be efficient as regards the availability of nutrients to the plants and as soil conditioner, due to its large surface area and high cation exchange capacity. These characteristics can alter the behavior of pesticides in soils increasing sorption and persistence, thus reducing their bioavailability and the leaching risk. ${ }^{16-19}$

Although biochar can mitigate the contamination of the environment by pesticides, there is a lack of information regarding the interactions between the forms of incorporation of biochar in soil as well as their effects on the efficiency of the active ingredient on pest and weed control. The objective of this study was to ascertain the capacity of biochar, produced by pyrolysis of organic solid residue from the sugar and alcohol industries (bagasse), as a mitigating agent for environmental contamination by the herbicide CMZ. In this work the effects of modes of application and incorporation of sugarcane bagasse biochar on the leaching and bioavailability of CMZ herbicide was evaluated. The results of this research are of great economic and environmental importance since it allows an alternative destination for the solid organic waste from the sugar and alcohol industries, increasing the added value of biomass and making the sugar cane production process more sustainable.

\section{Experimental}

\section{Chemicals}

The chemicals used were CMZ $(98.1 \%, \mathrm{~m} / \mathrm{m})$, anhydrous sodium sulfate and high performance liquid chromatography (HPLC) grade acetonitrile (both were purchased from Sigma-Aldrich, Seelze, Germany), ethyl acetate and sodium hydroxide (purchased from Vetec, Rio de Janeiro, Brazil), ortho-phosphoric acid (purchased from Merck Millipore, Darmstadt, Germany) and deionized water purified using a Millipore system (Merck Millipore, Darmstadt, Germany).

A stock standard solution (1000 $\mathrm{mg} \mathrm{L}^{-1}$ ) of CMZ was prepared by dilution in acetonitrile. The working solution was prepared at $250 \mathrm{mg} \mathrm{L}^{-1}$ and was used to prepare all solutions containing the herbicide employed in the optimization and validation of the method of analysis.

\section{Biochar preparation}

The biochar used in this work was produced by the pyrolysis of sugarcane bagasse. The sugarcane biomass (with $60 \%$ moisture content) was previously dried for $48 \mathrm{~h}$ at $60^{\circ} \mathrm{C}$ in a forced air circulation drying oven. The dried material was chopped in a disintegrator and pyrolyzed at $400{ }^{\circ} \mathrm{C}$ for $6 \mathrm{~h}$ under $\mathrm{CO}_{2}$ atmosphere in a laboratory muffle furnace, as described by Sun et al..$^{20}$ The resulting material was milled, dried at $60{ }^{\circ} \mathrm{C}$ for $12 \mathrm{~h}$, and sieved through $106 \mu \mathrm{m}$ mesh.

The $\mathrm{C}, \mathrm{H}, \mathrm{N}$ and $\mathrm{O}$ contents in biochar produced by pyrolysis were determined using a TruSpec CHNS/O Micro analyser (LECO Corp.) and the surface area was measured on a Quantachrome Nova 2200e instrument using $\mathrm{N}_{2}$ sorptometry. ${ }^{21}$

\section{Soil sampling}

An agricultural soil (red latosol with low organic matter content) was collected at $0-20 \mathrm{~cm}$ depth in an area without recent history of herbicide application, in the municipality of Tangará da Serra in Mato Grosso State, Brazil (14 39' 4.01" S, 57 26' 0.64" W). The soil was air dried and sieved through a $2 \mathrm{~mm}$ mesh. Subsequently, a $10 \mathrm{~kg}$ soil sample was amended with $1 \%(\mathrm{~m} / \mathrm{m})$ of biochar. Soil and biochar were manually mixed in polyethylene bucket.

Leaching assay

The influence of soil amendment with biochar on CMZ leaching was evaluated in a greenhouse experiment, adopting the completely randomized design in a split plot system, where the plots were composed of different masses of conditioned soil added at the top of the columns, and the subplots were the different depths of the column.

Polyvinyl chloride (PVC) columns of $10 \mathrm{~cm}$ diameter and $50 \mathrm{~cm}$ length were used in this experiment. The columns had their inner walls paraffinized to prevent formation of preferential flow paths on their surfaces and their bottom ends were closed with a qualitative filter paper coated with a thin nylon screen. The soil mass present in each column was ca. $4 \mathrm{~kg}$. The treatments were differentiated by addition of different masses of soil amended with $1 \%$ of biochar, in the upper part of the columns, as shown in Figure 1. The different masses of amended soil (with $1 \%$ of biochar) added to the column tops were: $80 \mathrm{~g}$ (equivalent to 0-1.0 cm depth); $200 \mathrm{~g}(0-2.5 \mathrm{~cm}$ depth); and $400 \mathrm{~g}$ (depth $0-5.0 \mathrm{~cm})$. Columns filled only with unmodified soil were similarly employed to verify the efficiency of the biochar on the CMZ leaching.

After being filled with soil, the columns were placed in a container with potable water for $48 \mathrm{~h}$ to eliminate all trapped air present into soil columns. Subsequently, the columns were removed from container and allowed to stand 


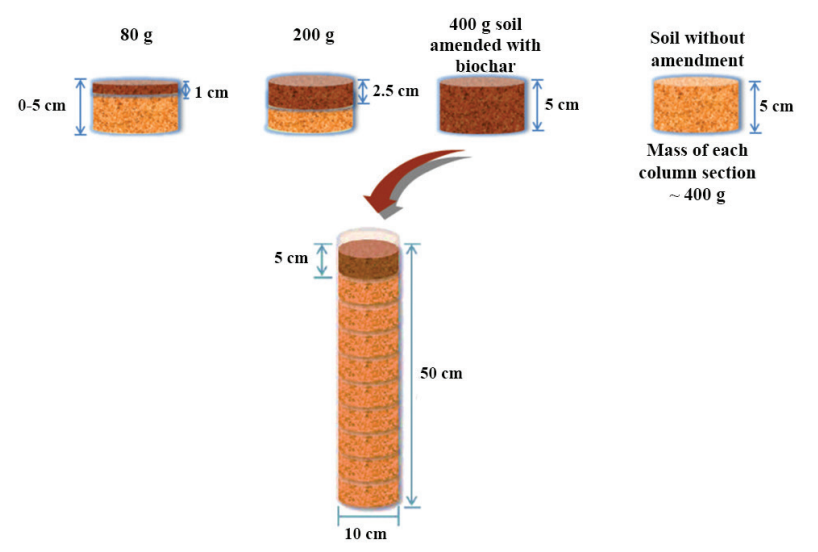

Figure 1. Schematic representation of soil columns used for development of leaching assay. The upper part of column received the addition of different masses (80, 200 and $400 \mathrm{~g}$ ) of amended soil with $1 \%(\mathrm{~m} / \mathrm{m})$ of biochar, which were added at different depths of the column (0-1.0, 0-2.5 and $0-5.0 \mathrm{~cm}$ ). Columns without addition of amended soil were used to evaluate the effect of biochar presence on the CMZ percolation.

upright for $72 \mathrm{~h}$ to eliminate excess water and to reach the field capacity of soil.

Afterwards, CMZ-based herbicide was diluted in water and applied on the top of the columns at $2 \mathrm{~kg} \mathrm{ha}^{-1}$ (twice the dosage recommended for weeds control in the sugarcane crop $)^{9}$ using a high precision backpack sprayer calibrated at $150 \mathrm{~L} \mathrm{ha}^{-1}$. It was estimated that each column received ca. $1.6 \mathrm{mg}$ of active principle. After $24 \mathrm{~h}$, rainfall of $60 \mathrm{~mm}$ for approximately $2 \mathrm{~h}$ was simulated, using a homemade simulator. Then, $72 \mathrm{~h}$ after rainfall simulation, the columns were sectioned in segments equivalent to depths of $0-5$, 5-10, 10-15, 15-20, 20-25, 25-30, 30-35, 35-40, 40-45 and $45-50 \mathrm{~cm}$, which were adopted as plots of the experimental design. All treatments were replicated three times. The soil samples from each section were homogenized and air dried for $48 \mathrm{~h}$. From each $5 \mathrm{~cm}$ section, approximately $100 \mathrm{~g}$ of soil were collected for HPLC analysis and ca. $300 \mathrm{~g}$ were transferred to $300 \mathrm{~mL}$ polypropylene vessels, which were used for performing the greenhouse bioassay.

\section{Greenhouse bioassay}

The bioavailability of CMZ, in the soil samples from leaching assay, was evaluated by greenhouse bioassay. ${ }^{22}$ The dried soil samples from each column sections were transferred to $300 \mathrm{~mL}$ polypropylene vessels, as abovementioned. Sorghum (Sorghum bicolor) was used as bioindicator species sensible to CMZ. Five sorghum seeds were sown in each vessel. These vessels were regularly watered to maintain the field capacity.

At 7 days after emergence, sorghum plants injury was visually rated as percentage of injury between 0 (absence of injury) and 100 (plant death).

\section{Analytical method}

The method using solid-liquid extraction with low-temperature partitioning (SLE/LTP) and analysis by HPLC with UV-Vis detection (HPLC-UV-Vis), proposed by Costa et al., ${ }^{23}$ was optimized and validated for determination of CMZ in soil and biochar-amended soil.

The optimization of the method was performed in soil amended with $1 \%(\mathrm{~m} / \mathrm{m})$ of biochar. In $50 \mathrm{~mL}$ polypropylene tube, $4.0000 \mathrm{~g}$ of amended soil sample was fortified with $40 \mu \mathrm{L}$ of CMZ solution at $250 \mathrm{mg} \mathrm{L}^{-1}$. The fortified sample was homogenized in vortex for $1 \mathrm{~min}$ and allowed to stand for $2 \mathrm{~h}$ to promote solvent evaporation and interactions between the matrix and the herbicide. Subsequently, $4.0 \mathrm{~mL}$ of pH-adjusted Milli-Q water with a $0.1 \mathrm{~mol} \mathrm{~L}^{-1} \mathrm{NaOH}$ and $8 \mathrm{~mL}$ acetonitrile/ethyl acetate $(6.50: 1.50 \mathrm{~mL})$ mixture were added to the sample. The tube was vortexed for $1 \mathrm{~min}$ and cooled at $-20{ }^{\circ} \mathrm{C}$ for $3 \mathrm{~h}$ to freeze the aqueous phase. The supernatant (ca. $7 \mathrm{~mL}$ organic phase) was collected, filtered on filter paper containing $1 \mathrm{~g}$ of anhydrous $\mathrm{Na}_{2} \mathrm{SO}_{4}$ (to remove remaining water), and evaporated in a rotary evaporator $\left(40{ }^{\circ} \mathrm{C}\right)$ to dryness. The analyte was recovered in $1 \mathrm{~mL}$ of acetonitrile, filtered through a Millipore filter $(0.45 \mu \mathrm{m})$, and analyzed by HPLC-UV-Vis.

\section{SLE / LTP optimization}

A factorial design $2^{3}$ was carried out to evaluate the simultaneous effect of the vortex agitation time, $\mathrm{pH}$ of the aqueous phase and volume of the extraction mixture, on CMZ extraction from $1 \%$ biochar-amended soil sample. All experiments of factorial design were run in triplicate and the best conditions were assessed using the chromatographic responses ( $\mathrm{CMZ}$ peak area) of each experiment (see Table S1, Supplementary Information (SI) section). The vortex agitation time was evaluated in periods of agitation of $1 \mathrm{~min}($ level $(-))$ and $3 \mathrm{~min}($ level $(+))$. The $\mathrm{pH}$ of the aqueous phase was evaluated using $0.1 \%(\mathrm{~m} / \mathrm{m}) \mathrm{H}_{3} \mathrm{PO}_{4}$ solution ((-) level, $\mathrm{pH}$ 2.2) and $\mathrm{pH}$-adjusted Milli-Q water with a $0.1 \mathrm{~mol} \mathrm{~L}^{-1} \mathrm{NaOH}((+)$ level, $\mathrm{pH} 8.0)$. Volumes of extraction mixture tested were $6 \mathrm{~mL}$ (level (-)) and $12 \mathrm{~mL}$ (level $(+)$ ), maintaining the extractive mixture composition at $33.3 \%$ of aqueous phase; $54.2 \%$ of acetonitrile and $12.5 \%$ ethyl acetate.

\section{HPLC analyses}

The chromatographic analyses were performed on an HPLC system (Shimadzu) equipped with an LC-20AT pump, a SIL-10AF autosampler, a CTO-10ASVP oven set at $30^{\circ} \mathrm{C}$, a C18 column (Shimadzu VP-ODS, $150 \times 4.6 \mathrm{~mm}$, $4.6 \pm 0.3 \mu \mathrm{m})$ and an SPD-20A UV-Vis detector set at $205 \mathrm{~nm}$. 
The chromatographic separation was performed using an isocratic mobile phase of acetonitrile and $0.1 \%$ phosphoric acid solution $(50: 50, \mathrm{v} / \mathrm{v})$, at a flow rate of $1.0 \mathrm{~mL} \mathrm{~min}^{-1}$. The injected sample volume was $20 \mu \mathrm{L}$ and the retention time of CMZ was $7.73 \mathrm{~min}$. Quantification of $\mathrm{CMZ}$ was performed by the matrix matched method.

\section{Method validation}

The optimized method was validated for CMZ analysis in biochar-amended soil and in the unamended soil. The figures of merit evaluated for the method were selectivity, linearity, limit of detection (LOD) and limit of quantification (LOQ), accuracy and precision (intra-day and inter-day precision). ${ }^{24-26}$

The selectivity was evaluated by comparison of the chromatograms obtained from the extracts of amended soil samples free and fortified with $2.5 \mathrm{mg} \mathrm{kg}^{-1}$ of CMZ. ${ }^{24,26}$

The linearity was established through matrix matched calibration graphs obtained by triplicate analysis of extracts of soil samples (soil and $1 \%$ biochar-amended soil) fortified in six concentration levels of CMZ (ranging from 32.5 to $400 \mu \mathrm{g} \mathrm{kg}^{-1}$ ). The ordinary least-squares method was used to establish the calibration curve and the residue graphs were evaluated to verify trends in the distribution of errors in the different concentrations analyzed..$^{24,27}$

The LOD and LOQ were determined using the ratio between standard deviation of the analytical responses generated by the blank analysis $(n=3)$ and the slope of the analytical curve. LOD and LOQ were obtained multiplying the ratio by 3.3 and 10 , respectively. ${ }^{25}$

The accuracy of the method was assessed through a recovery test. Samples of amended and unamended soils were fortified with 32.5, 200 and $400 \mu \mathrm{g} \mathrm{kg}^{-1}(\mathrm{n}=3)$ of the CMZ, extracted and quantified by the calibration curve obtained by the matrix matched method. The results were expressed as the percentage of recovery obtained by the ratio between average concentration determined experimentally and the corresponding theoretical concentration, multiplied by $100 .^{25}$

The precision was evaluated through the relative standard deviations (RSD) of the chromatographic areas obtained in the intra- and inter-day analysis of the fortified soil samples (amended and unamended soil) with 32.5, 200 and $400 \mu \mathrm{g} \mathrm{kg}^{-1}(\mathrm{n}=6)$. In the intra-day analysis, the sample preparations were performed in a single day and the CMZ determinations were performed by the same analyst and using the same chromatograph. In the inter-day analysis, the preparation of the samples and the determination of the pesticides were carried out on different days, non-consecutive, by the same analyst in the same equipment. . $^{24,25}$

\section{Determination of $\mathrm{CMZ}$ in soil samples from columns}

The quantification of CMZ in the samples from the column sections that received biochar-amended soil (samples of the 0-5 cm segment from treatments with biochar-amended soil) was performed through the matrix matched curve obtained in the $1 \%$ biochar-amended soil. All the other samples (soil samples from the sections without biochar) were quantified using the curve obtained in unamended soil. The samples from each segment were analyzed in duplicate, totaling 6 replicates for each plot since each treatment was assembled in triplicate.

\section{Results and Discussion}

Characteristics of biochar, soil and biochar-amended soil

The $\mathrm{C}, \mathrm{H}, \mathrm{N}$ and $\mathrm{O}$ contents in biochar produced by pyrolysis presented $78.5 \%$ of $\mathrm{C} ; 2.69 \%$ of $\mathrm{H} ; 0.48 \%$ of $\mathrm{N}$; and $12.2 \%$ of $\mathrm{O}$. The specific surface area measured by the Brunauer-Emmett-Teller (BET) method was found to be $255 \mathrm{~m}^{2} \mathrm{~g}^{-1}$.

The physicochemical characteristics of the soil and amended soil are presented in Table 2.

Table 2. Physicochemical characteristics of soil and soil amended by $1 \%$ of biochar

\begin{tabular}{|c|c|c|c|}
\hline \multicolumn{2}{|c|}{ Characteristic } & Soil & Amended soil \\
\hline \multicolumn{2}{|l|}{$\mathrm{pH}\left(\right.$ in $\left.\mathrm{H}_{2} \mathrm{O}\right)$} & 5.59 & 6.00 \\
\hline \multicolumn{2}{|l|}{$\mathrm{P} /\left(\mathrm{mg} \mathrm{kg}^{-1}\right)$} & 0.1 & 0.9 \\
\hline \multicolumn{2}{|c|}{$\mathrm{K}^{+} /\left(\mathrm{mg} \mathrm{kg}^{-1}\right)$} & 11 & 116 \\
\hline \multicolumn{2}{|c|}{$\mathrm{Mg}^{2+} /\left(\mathrm{mmol} \mathrm{kg}^{-1}\right)$} & 0.9 & 1.7 \\
\hline \multicolumn{2}{|c|}{$\mathrm{CEC}^{\mathrm{a}} /\left(\mathrm{mmol} \mathrm{kg}^{-1}\right)$} & 52.0 & 55.6 \\
\hline \multicolumn{2}{|c|}{$\mathrm{OM}^{\mathrm{b}} / \%(\mathrm{~m} / \mathrm{m})$} & 2.37 & 2.50 \\
\hline \multirow[t]{3}{*}{ Texture / \% } & sand $(>0.053 \mathrm{~mm})$ & 66.5 & 66.1 \\
\hline & silt $(0.053-0.002 \mathrm{~mm})$ & 10.3 & 9.0 \\
\hline & clay $(<0.002 \mathrm{~mm})$ & 23.2 & 22.9 \\
\hline
\end{tabular}

${ }^{\mathrm{a} C a t i o n i c ~ e x c h a n g e ~ c a p a c i t y ~ a t ~} \mathrm{pH} 7$; ${ }^{\mathrm{b}}$ organic matter. Analyses carried out in the Laboratório de Análise de Solo, Tecido Vegetal e Fertilizante from Universidade Federal de Viçosa, according to the methodology of Empresa Brasileira de Pesquisa Agropecuária (Embrapa). ${ }^{28}$

The physicochemical characteristics and texture of amended soil were similar to those of the authentic soil, with the exception of the potassium concentration that was elevated ca. 10-fold.

\section{Optimization of the extraction conditions (SLE/LTP)}

A factorial design $2^{3}$ was employed to evaluate the effects of the following factors on CMZ extraction from 
biochar-amended soil samples: $\mathrm{pH}$ of the aqueous solution, vortex stirring time and volume of the extraction solution. The Pareto diagram (Figure 2) shows the effects of the factors on the herbicide extraction. The results of analysis of variance (ANOVA) for the effects of factors on CMZ extraction is displayed in Table S2 (SI section).

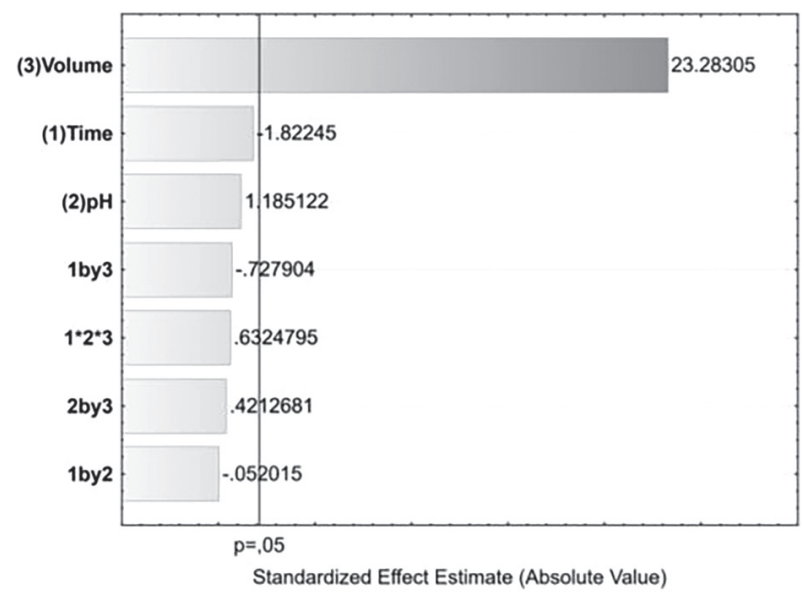

Figure 2. Pareto diagram of the effects of factors stirring time (1), $\mathrm{pH}$ of aqueous solution (2), and volume of extraction solution (3), on the CMZ extraction from biochar-amended soil samples using SLE/LTP.

The results presented in Figure 2 show that only the volume of the extraction solution presented significant effect on the chromatographic response (area) of CMZ at the level of $95 \%$ confidence $(\alpha<0.05)$. The use of the highest volume of extraction solution promoted a significant increase in the method extraction performance. This result is in accordance with the work published by Costa et al..$^{23}$ for analysis of fomesafen in different Brazilian soils.

The Pareto diagram showed that $\mathrm{pH}$ and stirring time did not significantly affect the extraction process. However, the chromatographic areas assigned to $\mathrm{CMZ}$ were slightly bigger in the experiments performed with the aqueous phase at $\mathrm{pH} 8$ and the stirring time in the vortex of $1 \mathrm{~min}$, then these conditions were adopted as the optimum $\mathrm{pH}$ and stirring time for the analyte extraction from soil. The higher chromatographic areas at pH 8 can be explained by the competition between the hydroxide ions present in aqueous solution (at $\mathrm{pH} 8$ ) and the $\mathrm{CMZ}$ by the soil sites that have low electron density (neutral site), such as metallic oxides and superficial aluminosilicates groups, which are responsible for sorption of the herbicide. ${ }^{29}$ This competition does not happen at low $\mathrm{pH}$ values. Thus, the herbicide shows higher sorption at low $\mathrm{pH}$ values, reducing the extraction efficiency of method.

So, the best experimental conditions were: aqueous solution at $\mathrm{pH} 8,1 \mathrm{~min}$ vortex stirring time and $12 \mathrm{~mL}$ of the extraction solution $(4.0 \mathrm{~mL}$ aqueous solution and $8 \mathrm{~mL}$ acetonitrile/ethyl acetate mixture).

\section{Method validation}

The selectivity was confirmed by comparing chromatograms of extracts obtained from biochar-amended soil fortified with $\mathrm{CMZ}$ and in the absence thereof, after application of SLE/LTP-HPLC-UV-Vis method. The chromatograms (Figure S1, SI section) showed the absence of peak from a coextractive at the $\mathrm{CMZ}$ retention time (7.73 $\mathrm{min})$ in the chromatogram from biochar-amended soil extract, proving the selectivity of the method.

The linearity expressed in terms of the determination coefficient $\left(\mathrm{R}^{2}\right)$ of the calibration curves (32.5 to $400 \mu \mathrm{g} \mathrm{kg}^{-1}$ ) was $\geq 0.99$ (Table 3 ). The residual plots showed the homoscedastic behavior of the data in all concentration ranges, in both matrices (Figure S2, SI section).

Table 3. Validation results of the optimized SLE/LTP-HPLC-UV-Vis method for CMZ determination in biochar-amended soil and unamended soil

\begin{tabular}{lccc}
\hline Method performance & & $\begin{array}{c}\text { Unamended } \\
\text { soil }\end{array}$ & $\begin{array}{c}\text { Biochar- } \\
\text { amended soil }\end{array}$ \\
\hline $\mathrm{R}^{2}$ & 0.992 & 0.990 \\
$\mathrm{LOD} /\left(\mu \mathrm{g} \mathrm{kg}^{-1}\right)$ & 6.5 & 4.1 \\
$\mathrm{LOQ} /\left(\mu \mathrm{g} \mathrm{kg}^{-1}\right)$ & 19.6 & 12.5 \\
Recovery $^{\mathrm{a}} \%$ & $32.5 \mu \mathrm{g} \mathrm{kg}^{-1}$ & $90.1 \pm 3.2$ & $92.5 \pm 3.7$ \\
& $200 \mu \mathrm{g} \mathrm{kg}^{-1}$ & $105.8 \pm 3.1$ & $98.3 \pm 7.9$ \\
& $400 \mu \mathrm{g} \mathrm{kg}^{-1}$ & $96.4 \pm 1.5$ & $102.0 \pm 2.6$ \\
Intra-day precision & $32.5 \mu \mathrm{g} \mathrm{kg}^{-1}$ & 12 & 11 \\
\% (RSD) & $200 \mu \mathrm{g} \mathrm{kg}^{-1}$ & 8 & 6 \\
& $400 \mu \mathrm{g} \mathrm{kg}^{-1}$ & 7 & 2 \\
Inter-day precision & $32.5 \mu \mathrm{g} \mathrm{kg}^{-1}$ & 17 & 16 \\
\% (RSD) & $200 \mu \mathrm{g} \mathrm{kg}^{-1}$ & 19 & 14 \\
& $400 \mu \mathrm{g} \mathrm{kg}^{-1}$ & 17 & 10 \\
\hline
\end{tabular}

${ }^{a} n=3 ;{ }^{b} n=6 ;{ }^{c} n=6$, assays carried out in three nonconsecutive days. $\mathrm{R}^{2}$ : determination coefficient; LOD: limit of detection; LOQ: limit of quantification; RSD: relative standard deviation.

The LOD and LOQ (Table 3) obtained using the SLE/LTP-HPLC-UV-Vis method are in line with limits presented in other analytical methods for $\mathrm{CMZ}$ determination. The LOQ obtained are close to those obtained by $\mathrm{Hu}$ et $a l .{ }^{30}$ using a solid phase extraction (SPE)-HPLC-diode array detector (DAD) method (10.0 $\left.\mu \mathrm{g} \mathrm{kg}^{-1}\right)$. Noldin et al. ${ }^{31}$ employed a SLE-gas chromatography (GC)-nitrogen-phosphorus detector (NPD) for CMZ analysis in gleissoil and obtained higher LOQ $\left(40.0 \mu \mathrm{g} \mathrm{kg}^{-1}\right)$ than that obtained in this work. 
The accuracy, expressed as the average percent recovery ( $\mathrm{n}=3$, at each concentration level), ranged from 90.1-105.8\% (Table 3). The intra-day precision, expressed as $\operatorname{RSD}(\mathrm{n}=6$, at each concentration level), ranged from $2-12 \%$ in the intra-day period. In the inter-day analysis, RSD varied between $10-19 \%$ (Table 3 ). These results indicate that the SLE/LTP-HPLC-UV-Vis method can be successfully applied for CMZ analysis in biochar-amended and unamended soil samples.

\section{Leaching experiments}

The validated SLE/LTP-HPLC-UV-Vis method was used for the determination of CMZ along the soil columns, which allowed us to evaluate the mobility of the herbicide through the columns. The treatments with higher mass of biochar in the first segment of column had a lower amount of CMZ extracted from the soil samples, due to the strong interactions between the herbicide and biochar. It was also observed for pentachlorophenol extraction from biocharamended soils. ${ }^{32}$ The results of CMZ leaching in the soil (authentic red latosol) and in treatments that received biochar-amended soil at different depths from columns are presented in Figure 3.

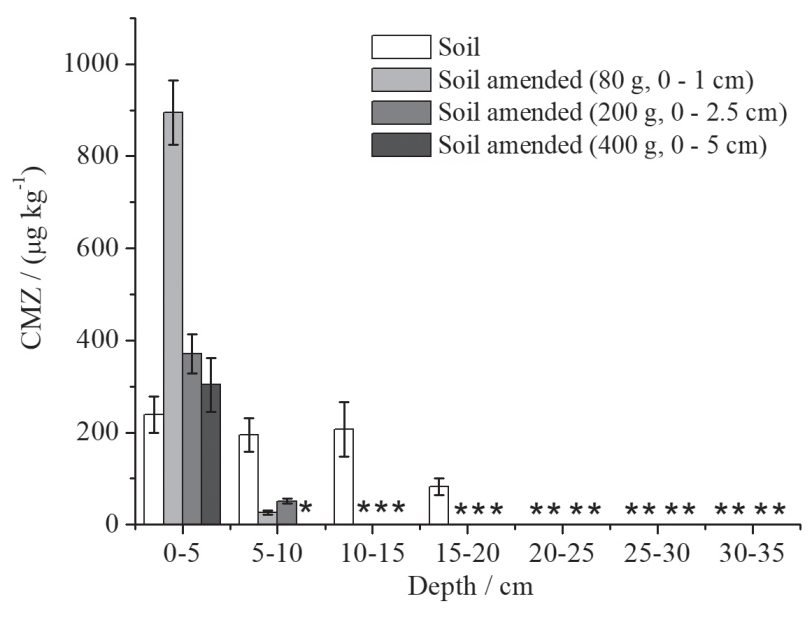

Figure 3. Concentrations of CMZ extracted from soil samples collected at different depths of the columns of the different treatments, after application of $2 \mathrm{~kg} \mathrm{CMZ} \mathrm{ha-1}$ on the columns top and $60 \mathrm{~mm}$ rain simulation. The treatments were differentiated by addition of different masses of biocharamended soil in the upper part of columns. The asterisks $(*)$ represent concentration lower than the LOQ of the method $\left(19.6 \mu \mathrm{g} \mathrm{kg}^{-1}\right)$.

The CMZ leached on columns filled with authentic soil to the depth of $20 \mathrm{~cm}$. The addition of biochar-amended soil in the first $5 \mathrm{~cm}$ of the columns improved the retention of $\mathrm{CMZ}$ in this soil layer, ${ }^{33}$ and the herbicide was found only in segments up to $10 \mathrm{~cm}$ deep in the columns. These results showed us a lower CMZ leaching in treatments with biochar-amended soil compared to columns filled with authentic soil, regardless of the biochar-amended soil mass (or depth) added on the column tops. It can be associated with the low sorption of CMZ in soil, which can be explained by its hydrophilic nature and low distribution coefficient $\left(\mathrm{K}_{\mathrm{d}}=0.47\right) .{ }^{33}$ Factors as moisture and organic matter content of soil can affect the herbicide retention in the soil colloids. ${ }^{10}$ Due to the high affinity of herbicide for soil organic matter, the presence of humic acids with broad aromatic domains, burning residues and biochar in the soil can strongly retain the CMZ, increasing its sorption. ${ }^{34,35}$ As biochar is an adsorbent that presents a large surface area, porosity and broad aromatic and hydrophobic domain, it presents a great capacity for sorption of organic contaminants, ${ }^{36}$ which increase CMZ retention and mitigate the herbicide leaching.

Similar results were presented by Delwiche et al., ${ }^{37}$ who observed that the biochar addition (at the an equivalent dose of $10 \mathrm{tha}^{-1}$ ) on the top of columns filled with a mixture of soil and industrial quartz sand (50:50), decreased the cumulative leaching of the pesticide atrazine by up to $52 \%$. In another study, Jones et al. ${ }^{17}$ evaluated the cumulative leaching of simazine $\left({ }^{14} \mathrm{C}\right)$ in smaller columns $(2.5 \mathrm{~cm})$ with surface application or full-filled with biochar-amended soil. In both cases, the presence of biochar decreased the pesticide leaching, compared to unamended soil.

The different forms of biochar incorporation in soil also contributed to the alteration of CMZ leaching. In the treatments that biochar-amended soil was added in the layers of $0-1.0$ and $0-2.5 \mathrm{~cm}, \mathrm{CMZ}$ was retained in the first $10 \mathrm{~cm}$ of the columns. The treatment that biocharamended soil was added between $0-5 \mathrm{~cm}$ on the top of the column showed an even greater efficiency in the retention of the herbicide, avoiding its percolation to greater depths compared to authentic soil. The form as the biocharamended soil was employed in the last treatment ( $400 \mathrm{~g}$ of amended soil, $0-5 \mathrm{~cm}$ ) allowed the immobilization of all $\mathrm{CMZ}$ in the first $5 \mathrm{~cm}$ of the column, showing the capacity of biochar to prevent the herbicide leaching under $60 \mathrm{~mm}$ rainfall. This result may be justified by the larger mass of biochar present in the last treatment. We highlighted that although the mass of CMZ applied in all treatments had been equal, the increase in mass of biochar-amended soil added on the columns top also increases the biochar mass. Due to the strong interactions between the herbicide and the biochar, the amount of CMZ extracted from the soil samples was lower, justifying the observed differences in the total concentration of CMZ in the different treatments.

The effect of biochar mass on organic compound leaching in soil was also observed by $\mathrm{Xu}$ et al., ${ }^{32}$ who evaluated the effects of different percentages of biochar 
(ranging from 1 to $5 \%$ ) on pentachlorophenol cumulative leaching in thinner and smaller columns $(30 \mathrm{~cm}$ height and $3 \mathrm{~cm}$ internal diameter) filled with amended soil. The authors showed that biochar presence led to a decrease of cumulative leaching of the pentachlorophenol by up to $42 \%$ in the treatments with larger mass of biochar (soil amended with $5 \%$ of biochar).

\section{Bioavailability assessment of $\mathrm{CMZ}$ along the column}

The results of greenhouse bioassay (Figure 4) corroborate the observations made using the results from chromatographic analysis that the biochar addition reduced the CMZ leaching in the soil. In addition, bioassay proved to be more sensitive for the detection of CMZ in the soil columns, showing the presence of the herbicide in the $25-30 \mathrm{~cm}$ segment from unamended soil columns. The higher sensitivity of the greenhouse bioassay method compared to the chromatographic analysis was also observed by Silva et al. ${ }^{38}$ In the evaluation of ametryne leaching in Brazilian soils, the authors observed that the species Cucumis sativus was able to detect the herbicide in greater depths than chromatographic analysis, showing the feasibility of using bioassays to obtain complementary information of pesticide leaching.

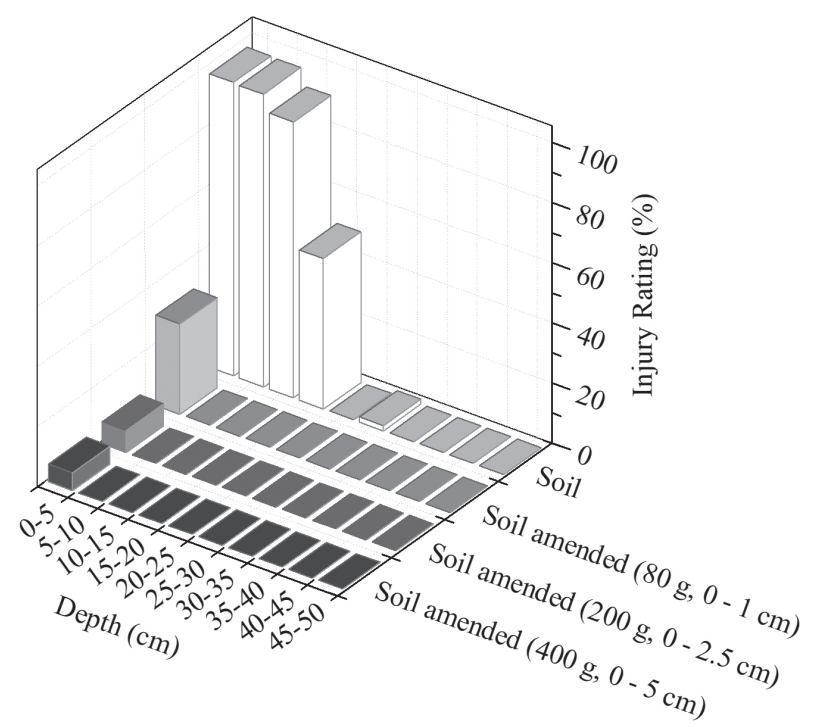

Figure 4. Injury percentage of sorghum plants 7 days after emergence as a function of column depth, in the treatments with biochar-amended soil on the column tops and in the unamended soil treatment.

Therefore, we observed that the CMZ leaching was reduced by $20 \mathrm{~cm}$ in the treatments, which received biocharamended soil additions in the layer of 0-1.0 and 0-2.5 cm, and in $25 \mathrm{~cm}$ in the treatment with biochar-amended soil in the $0-5 \mathrm{~cm}$ superficial layer.
In all treatments that received biochar-amended soil additions at top of the column, the CMZ presence was detected only in the superficial $5 \mathrm{~cm}$ (Figure 4), with low injury rate of the bioindicators $(<30 \%)$. These results show that although CMZ was in higher concentration in the first segment of the columns (Figure 3), its bioavailability has been reduced to the point where the herbicide was not efficient for the bioindicator control (in the treatment with soil amended between 0-5 cm, Figure 4). The lower bioavailability of the $\mathrm{CMZ}$ was caused by the high relative contributions of biochar to the soil sorptive capacity, ${ }^{39}$ which increases its retention and decreases bioavailability for controlling the sorghum plants.

These results were corroborated by studies carried out by Song et al. $^{40}$ In these studies, using earthworm as bioindicator, the authors evaluated the effect of amendment of soil with wheat straw biochar on the hexachlorobenzene bioavailability. They found that biochar provides a high sorption of the pesticide, reducing its accumulation into soil biota. The reduction of CMZ bioavailability in soils was observed by Xu et al. ${ }^{35}$ In a greenhouse study, these researchers evaluated the effect of soil amendment by residues from the burning of rice straw on the herbicide bioavailability and showed that $0.5 \%(\mathrm{~m} / \mathrm{m})$ of the material would be required to inhibit the plants injury caused by CMZ when applied to soil at the concentration of $0.3 \mu \mathrm{g} \mathrm{g}^{-1}$.

Thus, we verified that soil amendment with biochar is a good alternative to reduce the environmental risks caused by CMZ, reducing its bioavailability and the possibility of contamination of deeper layers of soil and groundwater. The results presented in Figures 3 and 4 allowed us to infer that application of $1 \%$ biochar in the first $5 \mathrm{~cm}$ of an authentic red latosol is enough to avoid the leaching of $\mathrm{CMZ}$ when two-fold of the recommended dosage of the herbicide was applied and the soil was submitted to $60 \mathrm{~mm}$ rainfall.

New leaching studies using soils with low sorption capacities, such as sand soils, and involving the biochar addition in surface layers, should be carried out to ratify biochar as a material that mitigates soil contamination by organic pollutants (such as pesticides). Another inference, about the results obtained in this research, is that the use of biochar in crops, which use pesticides on post-emergence, would be more appropriate, since it would reduce the risks of soil and groundwater contamination with pesticides without losing efficiency in the control of pests and diseases.

\section{Conclusions}

The optimized and validated SLE/LTP-HPLC-UV-Vis method was selective, precise and accurate for the determination of CMZ in biochar-amended and unamended 
soil, showing average recoveries above $90 \%$. The incorporation of sugarcane bagasse biochar in the soil was an effective strategy to reduce the herbicide leaching. The CMZ percolated up to $30 \mathrm{~cm}$ depth in the leach columns containing the unamended soil. The incorporation of $1 \%(\mathrm{~m} / \mathrm{m})$ of biochar in the first $5 \mathrm{~cm}$ layer of the column was enough to immobilize the CMZ. The bioassay showed that although CMZ was found in higher concentrations in the surface layers of columns with biochar-amended in soil, the bioavalability of the herbicide was reduced, avoiding the phytotoxicity of sorghum plants. Thus, the biochar of residual biomass from the sugar and alcohol industries combined with the proposed strategy of application can be an effective alternative to reduce the environmental contamination caused by the pesticide use.

\section{Supplementary Information}

Supplementary data (experimental design matrix, results of ANOVA and chromatograms) are available free of charge at http://jbcs.sbq.org.br as PDF file.

\section{Acknowledgments}

The authors thank the financial support provided by Conselho Nacional de Desenvolvimento Científico e Tecnológico (CNPq), Fundação de Amparo à Pesquisa do Estado de Minas Gerais (FAPEMIG) and Coordenação de Aperfeiçoamento de Pessoal de Nível Superior (CAPES).

\section{References}

1. USDE Global Ethanol Production 2016, available at https:// afdc.energy.gov/data/10331, accessed in June 2019.

2. Sindicato Nacional da Indústria de Produtos para Defesa Vegetal (SINDIVEG); Dados de Produção e Consumo de Agrotóxicos; available at http://sindiveg.org.br/estatisticas-dosetor/, accessed in June 2019.

3. Instituto de Pesquisa Econômica Aplicada (IPEA); Diagnóstico dos Resíduos Orgânicos do Setor Agrossilvopastoril e Agroindústrias Associadas; IPEA: Brasília, 2012.

4. Aditiya, H. B.; Mahlia, T. M. I.; Chong, W. T.; Nur, H.; Sebayang, A. H.; Renewable Sustainable Energy Rev. 2016, $66,631$.

5. Gonçalves, G. C.; Pereira, N. C.; Veit, M. T.; Biomass Bioenergy 2016, $85,178$.

6. Rabiu, S. D.; Auta, M.; Kovo, A. S.; Egypt. J. Pet. 2017, 27, 589.

7. Montero, J. I. Z.; Monteiro, A. S. C.; Gontijo, E. S. J.; Bueno, C. C.; de Moraes, M. A.; Rosa, A. H.; Ecotoxicol. Environ. Saf. 2018, 162, 616.
8. da Silva, L. F.; Gomez, J. G. C.; Rocha, R. C. S.; Taciro, M. K.; Pradella, J. G. D. C.; Quim. Nova 2007, 30, 1732.

9. Ministério da Agricultura, Pecuária e Abastecimento (MAPA); AGROFIT; MAPA: Brasília, 2003. Available at http://extranet. agricultura.gov.br/agrofit_cons/principal_agrofit_cons, accessed in June 2019.

10. Van Scoy, A. R.; Tjeerdema, R. S.; Rev. Environ. Contam. Toxicol. 2014, 229, 35.

11. International Union of Pure and Applied Chemistry (IUPAC); Pesticide Properties Database. Available at http://sitem.herts. ac.uk/aeru/iupac/Reports/168.htm, accessed in June 2019.

12. Silva, A. A.; Vivian, R.; Oliveira Jr., S. R. In Tópicos em Manejo de Plantas Daninhas; Silva, A. A.; Silva, J. F., eds.; Editora UFV: Viçosa, 2007, p. 155.

13. Li, L.; Li, G.; Yang, R.; Guo, Z.; Liao, X.; J. Environ. Sci. 2004, 16,678 .

14. Miron, D. S.; Pretto, A.; Crestani, M.; Glusczak, L.; Schetinger, M. R.; Loro, V. L.; Morsch, V. M.; Chemosphere 2008, 74, 1.

15. Miron, D. S.; Silva, L. V. F.; Golombieski, J. I.; Machado, S. L. O.; Marchezan, E.; Baldisserotto, B.; Cienc. Rural 2004, 34, 1465.

16. Glaser, B.; Lehmann, J.; Zech, W.; Biol. Fertil. Soils 2002, 35 , 219.

17. Jones, D. L.; Edwards-Jones, G.; Murphy, D. V.; Soil Biol. Biochem. 2011, 43, 804.

18. Wang, Z.; Han, L.; Sun, K.; Jin, J.; Ro, K. S.; Libra, J. A.; Liu, X.; Xing, B.; Chemosphere 2016, 144, 285.

19. Liu, K.; He, Y.; Xu, S.; Hu, L.; Luo, K.; Liu, X.; Liu, M.; Zhou, X.; Bai, L.; Ecotoxicol. Environ. Saf. 2018, 161, 602.

20. Sun, K.; Gao, B.; Ro, K. S.; Novak, J. M.; Wang, Z.; Herbert, S.; Xing, B.; Environ. Pollut. 2012, 163, 167.

21. Mukherjee, A.; Lal, R.; Zimmerman, A. R.; Sci. Total Environ. 2014, 487, 26.

22. Neto, M. D. C.; Souza, M. F.; Silva, D. V.; Faria, A. T.; da Silva, A. A.; Pereira, G. A. M.; de Freitas, M. A. M.; Arch. Agron. Soil Sci. 2016, 63, 897.

23. Costa, A. I. G.; Queiroz, M. E. L. R.; Neves, A. A.; de Assis, R. C.; dos Soares, C. E. S.; da Silva, A. A.; D’Antonino, L.; de Oliveira, A. F.; Bellato, C. R.; Environ. Sci. Pollut. Res. Int. 2015, 22, 3457.

24. Instituto Nacional de Metrologia, Qualidade e Tecnologia (Inmetro); Orientação Sobre Validação de Métodos Analíticos; Inmetro: Rio de Janeiro, 2011.

25. Agência Nacional de Vigilância Sanitária (ANVISA); Resolução da Diretoria Colegiada-RDC No. 166, de 24 de julho de 2017; Diário Oficial da União: Brasília, 2017.

26. Ribani, M.; Bottoli, C. B. G.; Collins, C. H.; Jardim, I. C. S. F.; Melo, L. F. C.; Quim. Nova 2004, 27, 771.

27. Dionisio, A. C.; Rath, S.; Chemosphere 2016, 151, 17.

28. Empresa Brasileira de Pesquisa Agropecuária (Embrapa); Manual de Métodos de Análise de Solo; Embrapa: Rio de Janeiro, 1997. 
29. MacKay, A. A.; Vasudevan, D.; Environ. Sci. Technol. 2012, 46, 9209.

30. Hu, J.; Cao, D.; Deng, Z.; Bull. Environ. Contam. Toxicol. 2011, 86, 444.

31. Noldin, J. A.; Hermes, L. C.; Fay, E. F.; Eberhardt, D. S.; Rossi, M. A.; Planta Daninha 2001, 19, 401.

32. Xu, T.; Lou, L.; Luo, L.; Cao, R.; Duan, D.; Chen, Y.; Sci. Total Environ. 2012, 414, 727.

33. da Silva, M. R. F.; de Queiroz, M. E. L. R.; Neves, A. A.; da Silva, A. A.; de Oliveira, A. F.; de Oliveira, R. L.; Azevedo, M. M.; An. Acad. Bras. Cienc. 2018, 90, 3745.

34. Gunasekara, A. S.; dela Cruz, I. D. P.; Curtis, M. J.; Claassen, V. P.; Tjeerdema, R. S.; Pest Manage. Sci. 2009, 65, 711.

35. Xu, C.; Liu, W.; Sheng, G. D.; Sci. Total Environ. 2008, 392, 284.
36. Wang, X.; Xing, B.; Environ. Sci. Technol. 2007, 41, 8342.

37. Delwiche, K. B.; Lehmann, J.; Walter, M. T.; Chemosphere 2014, 95, 346.

38. Silva, L. O. C.; Silva, A. A.; Queiroz, M. E. L. R.; Lima, C. F.; Silva, L. L.; D’Antonino, L.; Planta Daninha 2012, 30, 883.

39. Gámiz, B.; Velarde, P.; Spokas, K. A.; Hermosín, M. C.; Cox, L.; J. Agric. Food Chem. 2017, 65, 3109.

40. Song, Y.; Wang, F.; Bian, Y.; Kengara, F. O.; Jia, M.; Xie, Z.; Jiang, X.; J. Hazard. Mater. 2012, 217-218, 391.

Submitted: January 18, 2019

Published online: July 2, 2019 